\title{
REKAYASA PERANGKAT LUNAK SISTEM MONITORING DAN EVALUASI PROGRAM PEMBANGUNAN DESA
}

\author{
Zyad Rusdi $^{1}$, Dedi Trisnawarman ${ }^{2}$ \\ ${ }^{1,2}$ Program Studi Sistem Informasi, Fakultas Teknologi Informasi, Universitas Tarumanagara, \\ Jln. Letjen S. Parman No. 1, Jakarta, 11440, Indonesia \\ E-mail:'Iyadr@fti.untar.ac.id, 2dtrisnawarman@gmail.com
}

\begin{abstract}
Abstrak
Program pembangunan desa menjadi perhatian besar dari pemerintah pusat. Hal ini diwujudkan dalam UU no. 6 tahun 2014 dan pembagian dana desa yang berjumlah besar. Desa memiliki kewenangan dan sumberdaya yang besar dalam mewujudkan tujuan program pembangunan desa. Namun proses pembangunan desa harus dimonitoring dan dievaluasi agar tujuan yang direncanakan dapat terwujud.

Penelitian ini bertujuan membangun sebuah software aplikasi yang dapat digunakan sebagai instrumen untuk melakukan monitoring, evaluasi dan prediksi dalam proses pembangunan desa. Metode yang digunakan adalah metode rekayasa perangkat lunak prototyping yang melibatkan pengguna dan disesuaikan dengan metodelogi pembangunan dashboard. Tahapan pembangunan dashboard teridiri dari identifikasi key perfomance indicator, analisis, desain fungsi, desain dashboard, dan testing.

Penelitian ini menghasilkan sebuah software aplikasi berbasis web dengan domain desapandai.com, yang dapat digunakan untuk membantu pemerintahan desa melakukan monitoring, evaluasi dan pengambilan keputusan dalam proses pembangunan desa.
\end{abstract}

Kata kunci: dashboard, pembangunan, desa, software, monitoring, evaluasi

\begin{abstract}
Village development programs are a major concern of the central government. This is manifested in Law no. 6 of 2014 and the substantial distribution of village funds. Villages have considerable authority and resources in realizing the objectives of the village development program. However, the village development process should be monitored and evaluated so that the planned objectives can be realized.

This study aims to build an application software that can be used as an instrument to perform monitoring, evaluation and prediction in the process of village development. The method used is a prototyping software engineering method that involves the user and adapted to the dashboard development methodology. Stages of dashboard development consist of identification key perfomance indicator, analysis, function design, dashboard design, and testing.
\end{abstract}

This research produces a web based application software with desapandai.com domain, which can be used to assist village administration in monitoring, evaluation and decision making in village development process.

Keywords: dashboard, development, village, software, monitoring, evaluation 


\section{PENDAHULUAN}

Pelaksanaan program-program pembangunan desa kini telah memasuki tahun ketiga sejak diterbitkannya UU Desa No 6 Tahun 2014 dan pembagian dana desa. Hingga saat ini sudah banyak program pembangunan yang dilaksanakan. Namun demikian, untuk melihat tingkat keberhasilan dan ketercapaian tujuan program, perlu kiranya dilakukan kegiatan monitoring dan evaluasi terhadap manfaat program-program pembangunan desa.

Dalam upaya mendorong sistem monitoring dan evaluasi yang efektif terhadap program/kegiatan pembangunan yang telah dilakukan oleh Pemerintah desa, diperlukan instrumen monitoring dan evaluasi manfaat program pembangunan. Untuk itulah penelitian ini dilakukan dengan harapan akan menghasilkan instrumen monitoring dan evaluasi manfaat program pembangunan di desa sebagai sebuah langkah awal untuk dapat dilakukannya kegiatan monitoring dan evaluasi yang lebih efektif.

Sejak diberlakukannya otonomi daerah, tugas pembangunan daerah menjadi tanggung jawab Pemerintah daerah masing-masing. Dengan adanya UU sistem Pemerintahan Daerah, maka pemerintah daerah mempunyai kewenangan mengatur wilayahnya sendiri dengan batasanbatasan tertentu. Tuntutan untuk keberhasilan pembangunan desa sebagaimana amanat UU No. 6 tahun 2014 telah "memaksa" pimpinan daerah untuk mengoptimalkan sistem pemerintahannya, salah satunya dengan jalan pengembangan dan penerapan teknologi informasi yang sejalan dengan visi pembangunan daerah.

Salah satu penerapan aplikasi teknologi informasi adalah untuk membantu melakukan monitoring, evaluasi dan pengambilan keputusan. Aplikasi tersebut mampu mengintegrasikan beragam sumber data, menampilkan tampilan analisis, dan prediksi terhadap suatu masalah.

Organisasi sering kali dihadapkan pada perubahan lingkungan bisnis yang semakin cepat. Organisasi perlu melakukan monitoring dan pengukuran secara terus-menerus untuk memastikan bahwa proses bisnis yang dijalankannya dapat mencapai tujuan yang ditetapkan, melalui strategi pengelolaan yang tepat. Pengukuran kondisi organisasi memerlukan data dan informasi yang tepat dari seluruh bagian organisasi. Informasi tersebut juga harus disampaikan kepada pihak yang tepat, pada waktu yang tepat pula.

Information dashboard merupakan alat untuk menyajikan informasi secara sekilas, solusi bagi kebutuhan informasi organisasi [1]. Information dashboard memberikan tampilan antarmuka dengan berbagai bentuk seperti diagram, laporan, indikator visual, mekanisme alert, yang dipadukan dengan informasi yang dinamis dan relevan [2]. Information dashboard mengumpulkan informasi yang relevan dari berbagai bagian organisasi, mengkonsolidasikan, dan menyampaikan secara aman, cepat, dengan personalisasi sesuai dengan peran pengguna dalam organisasi [3], Tujuan penggunaan information dashboard, untuk mengukur kinerja, memonitor proses yang sedang berjalan, dan memprediksi kondisi di masa mendatang [4]

Metodologi dashboard adalah interdisipliner dan luas, mencakup beberapa domain aplikasi. Termasuk bidang teori keputusan, dengan mengumpulkan dan menyimpan data dimaksudkan untuk memfasilitasi proses pengambilan keputusan, dan teknologi data warehouse; dengan model matematika untuk optimasi dan data mining, riset operasi dan statistik, dihubungkan dengan beberapa aplikasi seperti pemasaran, akuntansi logistik, dan pengendalian, keuangan, jasa dan administrasi publik. Lingkungan dashboard menawarkan informasi pembuat keputusan dan pengetahuan yang diperoleh dari pengolahan data, melalui penerapan matematika model dan algoritma [5].

Dashboard adalah program sistematis dan etis untuk mengumpulkan, menganalisis dan mengelola informasi eksternal yang dapat mempengaruhi rencana, keputusan dan operasi organisasi. Dengan kata lain, dashboard adalah proses untuk memastikan daya saing melalui 
pemahaman yang lebih besar dari pesaing dan lingkungan yang kompetitif secara keseluruhan. Dashboard yang diperoleh berasal dari sumber yang tersedia untuk semua orang [6], seperti:

- pemerintah dan laporan situs web basis data online, wawancara atau survei

- kelompok kepentingan khusus (seperti akademisi, asosiasi perdagangan, dan konsumen kelompok)

- sumber sektor swasta (seperti pesaing, pemasok, pelanggan distributor,) media (jurnal, layanan kawat, surat kabar, dan laporan keuangan).

Pembangunan desa hakekatnya merupakan pembangunan nasional dan menjadi prioritas dalam rencana kerja pemerintahan saat ini. UU desa no. 6 tahun 2014 dan dana desa merupakan bukti nyata kesungguhan pemerintah dalam pembangunan desa. Namun kesungguhan pemerintah tersebut harus diikuti dengan instrumen pengawasan dan evaluasi agar tujuan pembangunan desa dapat tercapai. Penelitian ini bermaksud membangun instrumen yang dapat melakukan pengawasan dan evaluasi serta membantu dalam pengambilan keputusan proses pembangunan desa.

\section{METODE PENELITIAN}

\subsection{Kajian Pustaka}

\subsubsection{Dashboard Pemerintahan}

Beberapa penelitian tentang dashboard yang diterapkan dalam pemerintahan dan melibatkan partisipan sudah pernah dilakukan. Berikut ini beberapa penelitian yang telah dilakukan.

Suatu model baru dalam sistem egovernment yaitu intelligent egovernment model. Model dibagi menjadi dua yaitu civic centric service dan civilian collaboration. Metode yang digunakan mampu membangun knowledge dari data yang berupa pertanyaan yang terakumulasi selama proses administrasi, selanjutnya menggunakan text mining dengan algoritma klasifikasi mampu menyediakan rantai jawaban terhadap pertanyaan yang diajukan secara otomatis [7]. Posayanant dan Chareonngam, membahas tentang penerapan indikator kinerja utama atau Key Perfomance Indicator (KPI) berdasarkan pada integrasi Balanced Scorecard (BSC) dan pendekatan rantai nilai atau Value Chain. Implementasi metode ini digunakan untuk penilaian perkembangan proyek infrastruktur di daerah pedesaan di pemerintahan lokal di negara Thailand [7].

Penelitian tentang pemodelan dashboard yang melibatkan partisipan khusus untuk meningkatkan aplikasi dashboard juga telah dilakukan oleh Dolan et al, membangun model dashboard dalam bentuk Interactive Clinical Decision Dashboard, menggunakan kuisioner dan analisis kualitatif data dari para sukarelawan [8]. Begitu juga Murray et al. (2013) membangun aplikasi dashboard untuk menganalisis indicator dialog dengan menggunakan data registrasi partisipan yaitu mediator, guru, dan facilitator [9].

\subsubsection{Monitoring dan Evaluasi}

Monitoring merupakan aktivitas internal proyek yang dirancang untuk mengidentifikasi feedback konstan pada setiap progres dari proyek tersebut, termasuk masalah-masalah yang dihadapi dan efisiensi dari implementasi proyek tersebut [10].

Monitoring lebih dimaksudkan untuk menilai apakah sumber proyek (input) akan dilaksanakan dan digunakan dalam menghasilkan output yang dituju. Sementara itu evaluasi merupakan proses penilaian pencapaian tujuan dan pengungkapan masalah kinerja 
program/kegiatan untuk memberikan umpan balik bagi peningkatan kualitas kinerja program/kegiatan. Evaluasi pada dasarnya akan bermanfaat dalam merancang proyek-proyek yang lebih baik di masa depan. Hal ini terkait dengan manfaat evaluasi itu sendiri yang mampu mengidentifikasi dampak dari sebuah proyek, sehingga dampak negatifnya dapat direduksi bahkan dihilangkan [10]. Tidak adanya sistem evaluasi yang efektif pada sebuah proyek dapat mengakibatkan dampak negatif dari proyek tersebut akan semakin meningkat karena tidak mampu menghasilkan keuntungan yang diharapkan [10].

Penelitian tentang monitoring dan evaluasi kegitan pembangunan di kota Semarang dilakukan oleh Muktiali. Dalam penelitiannya Muktiali membangun instrumen untuk kegiatan monitoring dan evaluasi terhadap manfaat program-program pembangunan Kota Semarang. Hasil penelitian tersebut menghasilkan beberapa rekomendasi terkait pelaksanaan kegiatan monitoring dan evaluasi manfaat program pembangunan Kota Semarang [11] yaitu:

1. Pelaksanaan monitoring dan evaluasi manfaat program pembangunan perlu melibatkan berbagai pihak terkait, dalam hal ini SKPD-SKPD Kota Semarang sesuai dengan fungsi pemerintahan masing-masing, hal ini bertujuan untuk mempermudah pelaksanaan kegiatan monev di Kota Semarang

2. Penyusunan program-program pembangunan yang terdapat dalam RPJMD Kota Semarang perlu didasarkan pada analisis terhadap permasalahan yang terjadi sehingga program yang disusun mampu menjawab permasalahan-permasalahan yang ada dan tepat sasaran. Dalam hal penyusunan indikator sasaran untuk masing - masing program hendaknya perlu dinyatakan dalam sesuatu yang terukur (jumlah, prosentase, rasio atau tingkatan) sehingga lebih mudah untuk dievaluasi kinerjanya.

3. Instrumen-instrumen yang telah tersusun harapannya dapat digunakan sebagai arahan untuk menyusun indeks agregat setiap program, urusan maupun SKPD, sehingga dapat dilihat tingkat ketercapaian/kinerja untuk setiap program, urusan maupun SKPD.

4. Guna meningkatkan validitas dan kesahihan data, maka perlu dilakukan penyusunan basis data untuk masing - masing urusan (SKPD) secara transparan dan akuntabel.

5. Perlu dilakukan studi lanjutan mengenai instrumen monitoring untuk masing-masing urusan atau bahkan masing-masing program, sehingga dapat lebih detail menjelaskan kertas kerja instrumen monitoring dan evaluasi yang secara teknis dapat diaplikasikan.

Indikator-indikator dalam mengukur kinerja pembangunan meliputi; indikator input, indikator output, indikator outcome, indikator dampak, dan indikator manfaat [12]. Rumus untuk menyusun indikator dikenal dengan istilah SMART yaitu: Specific; tujuan harus secara khusus menggambarkan hal-hal yang diinginkan, Measurable; tujuan harus dapat dijabarkan dalam indikator yang terukur, Attainable; tujuan harus dapat dicapai dengan kondisi sumberdaya \& potensi yang ada, Relevant; tujuan harus relevan dengan kebutuhan informasi dan pengelolaan yang ada, Timely [12]; tujuan harus tepat waktu dalam arti kondisi yang diperlukan dan kebutuhan yang berkembang.

\subsection{Metode Penelitian}

Metodologi pembangunan dashboard yang diusulkan dalam penelitian ini merupakan pengembangan dari metodologi pembangunan dashboard yang memiliki 7 (tujuh) tahapan utama, sesuai dengan tahapan dalam pengembangan sistem perangkat lunak, yaitu identifikasi kebutuhan,perencanaan, perancangan prototype, review prototype, implementasi, deployment, dan maintenance [13].

Metodologi pembangunan dashboard yang diusulkan dalam penelitian ini terdiri dari beberapa tahap yaitu tahap: pengumpulan data untuk mengidentifikasi key perfomance indikator, analisis, desain dan testing. Semua tahapan dalam pembangunan dashboard 
melibatkan user secara interaktif, sesuai dengan metode prototyping. Gambaran tahapan pengembangan dashboard dapat dilihat pada Gambar 1

KEY PERFOMANCE INDICATOR

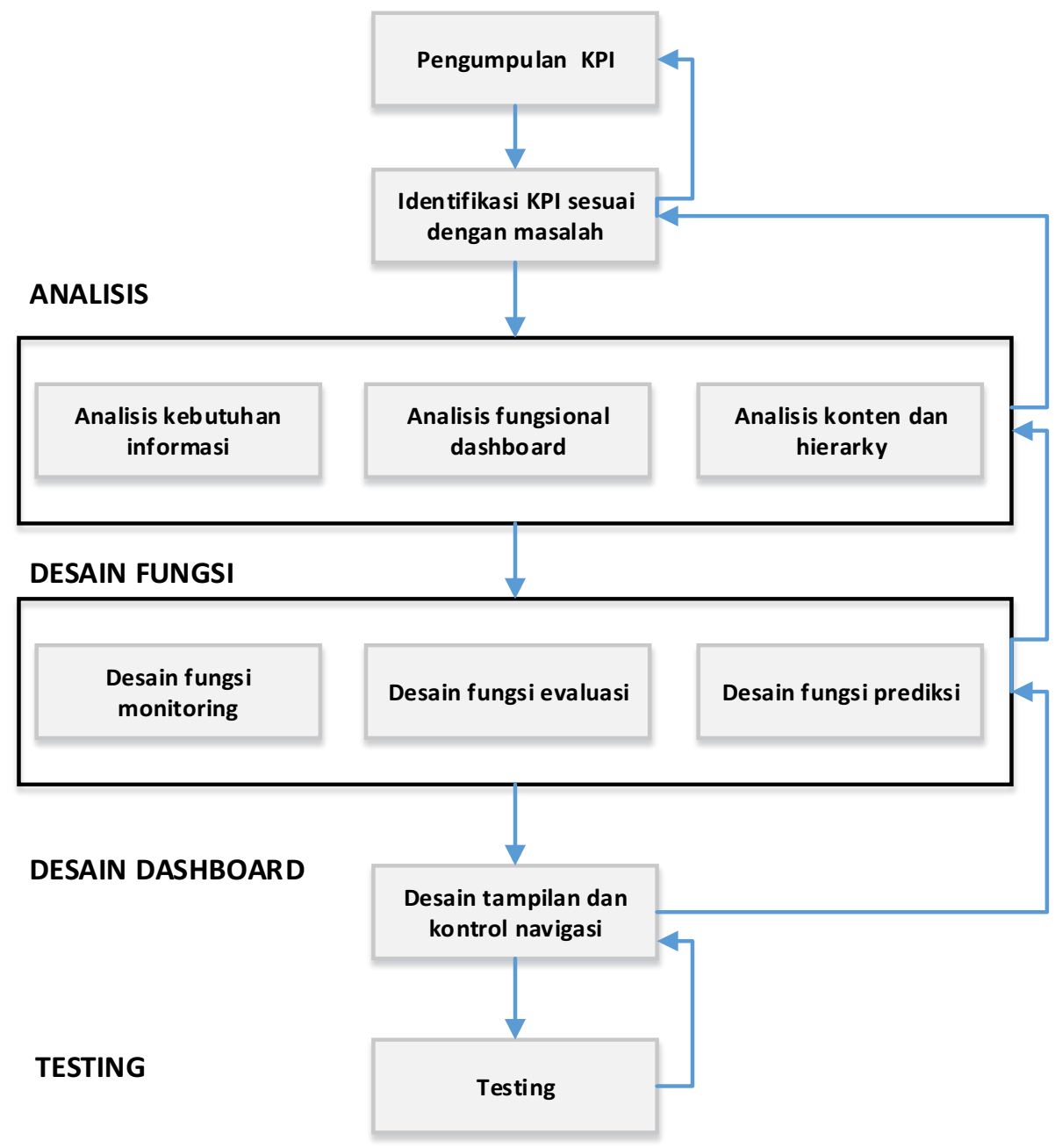

Gambar 1. Metode Pengembangan Dashboard

\section{HASIL DAN PEMBAHASA}

\subsection{Identifikasi Kebutuhan KPI}

Identifikasi kebutuhan KPI adalah langkah awal yang dilakukan dalam tahapan pengembangan dashboard. Dimulai dari identifikasi high-level scenario dashboard untuk mendapatkan gambaran umum skenario informasi yang akan disajikan pada dashboard. Dari high-level scenario, selanjutnya diidentifikasi kebutuhan data/informasi secara detail, sampai didapatkan KPI untuk setiap jenis dashboard.

Identifikasi kebutuhan data/informasi dilakukan melalui dua cara yang dilakukan secara bersamaan, yaitu dengan identifikasi KPI organisasi yang berada dalam lingkup pembangunan dashboard, dan identifikasi kebutuhan bisnis pengguna dashboard. Selanjutnya, hasil identifikasi KPI organisasi dipetakan dengan kebutuhan bisnis dari setiap pengguna, sehingga diperoleh KPI untuk setiap jenis dashboard. Hal ini dilakukan karena tidak semua KPI organisasi disajikan pada dashboard. Dashboard hanya menyajikan KPI yang mendukung kebutuhan pengguna dalam membuat keputusan atau tindakan bisnis. 
Tahap identifikasi kebutuhan dilakukan dengan melibatkan pihak pengguna secara aktif, mulai dari pimpinan sampai dengan perwakilan dari tiap kelompok pengguna yang nantinya akan menggunakan dashboard. KPI program pembangunan desa dapat dilihat berdasarkan dokumen Rencana Pembangunan Jangka Menengah Desa dan Rencana Kerja Pembangunan Desa. Berdasarkan dokumen-dokumen tersebut, dapat disimpulkan bahwa pada program pembangunan desa memiliki 4 (empat) bidang KPI, yaitu usulan program, kegiatan, potensi, pengusul.

Identifikasi KPI untuk monitoring dan evaluasi program pembangunan desa adalah sebagai berikut:

1. Usulan program, adalah usulan program atau kegiatan yang berasal dari masyarakat, yang berkaitan dengan permasalahan yang ada di desa. Usulan ini dibagi menjadi beberapa jenis atau kategori, yaitu bidang fisik atau pembangunan fisik, bidang ekonomi, bidang kesehatan, bidang pendidikan, bidang sosial budaya, bidang keagamaan. Dalam usulan program informasi yang diperlukan untuk analisis pengambilan keputusan adalah; nama program, jenis program, pengusul, tanggal usulan, detail atau deskripsi usulan.Dalam usulan program dimungkinkan untuk mengunggah foto usulan

2. Kegiatan atau aktivitas yang dilakukan oleh masyarakat desa yang berkaitan dengan pembangunan desa. Informasi yang dibutuhkan adalah; nama kegiatan, tanggal kegiatan, deskripsi kegiatan, dan penanggung jawab kegiatan.

3. Potensi, adalah sumberdaya yang menjadi pendukung dalam pelaksanaan program atau kegiatan pembangunan. Informasi yang dibutuhkan dari potensi adalah; nama lokasi, jenis potensi, deskkripsi potensi, lokasi potensi, alamat potensi, penduduk yang berhubungan dengan potensi tersebut atau pemilik potensi, dan tanggal potensi diunggah

4. Pengusul adalah masyarakat desa yang mengajukan usulan program pembangunan desa. Informasi pengusul dikaitkan dengan informasi penduduk desa, seperti; nama, alamat, pekerjaan dan data demografi penduduk desa.

\subsection{Analisis}

Tahap berikutnya adalah tahap analisis, bertujuan untuk menganalisis data yang diperoleh dari hasil identifikasi kebutuhan. Tahap analisis terdiri dari tiga bagian yaitu: analisis kebutuhan informasi, analisis fungsional dan analisis konten dan hierarky. Analisis kebutuhan informasi yaitu analisis kebutuhan terhadap sumber data yang tersedia, meliputi basisdata yang sedang berjalan atau sumber lain yang berhubungan. Pada tahap analisis fungsi yaitu menentukan fungsi-fungsi yang dibutuhkan dan yang dapat disediakan dalam aplikasi dashboard. Fungsifungsi yang dimaksud membangun tampilan informasi yang akan dianalisis, fungsi alert atau monitoring dan fungsi prediksi dengan menggunakan algoritma-algoritma dalam metode data mining. Tahapan analisis berikutnya adalah menganalisis kebutuhan informasi untuk mengisi konten dashboard dan mengurutkannya berdasarkan hierarky atau struktur tingkatan informasi yang dibutuhkan.

\subsubsection{Analisis kebutuhan informasi}

Analisis kebutuhan informasi berhubungan dengan kebutuhan data untuk menyediakan informasi yang dibutuhkan. Kebutuhan informasi dihubungkan dengan KPI yang telah diidentifikasikan sebelumnya. Kebutuhan informasi yang bersumber dari basisdata yang saat ini tengah berjalan yaitu online transaction processing (OLTP). OLTP yang digunakan dalam penelitian ini adalah basisdata kegiatan program pembangunan desa yang sedang berjalan, Gambar 2. menunjukan OLTP program pembangunan desa. 


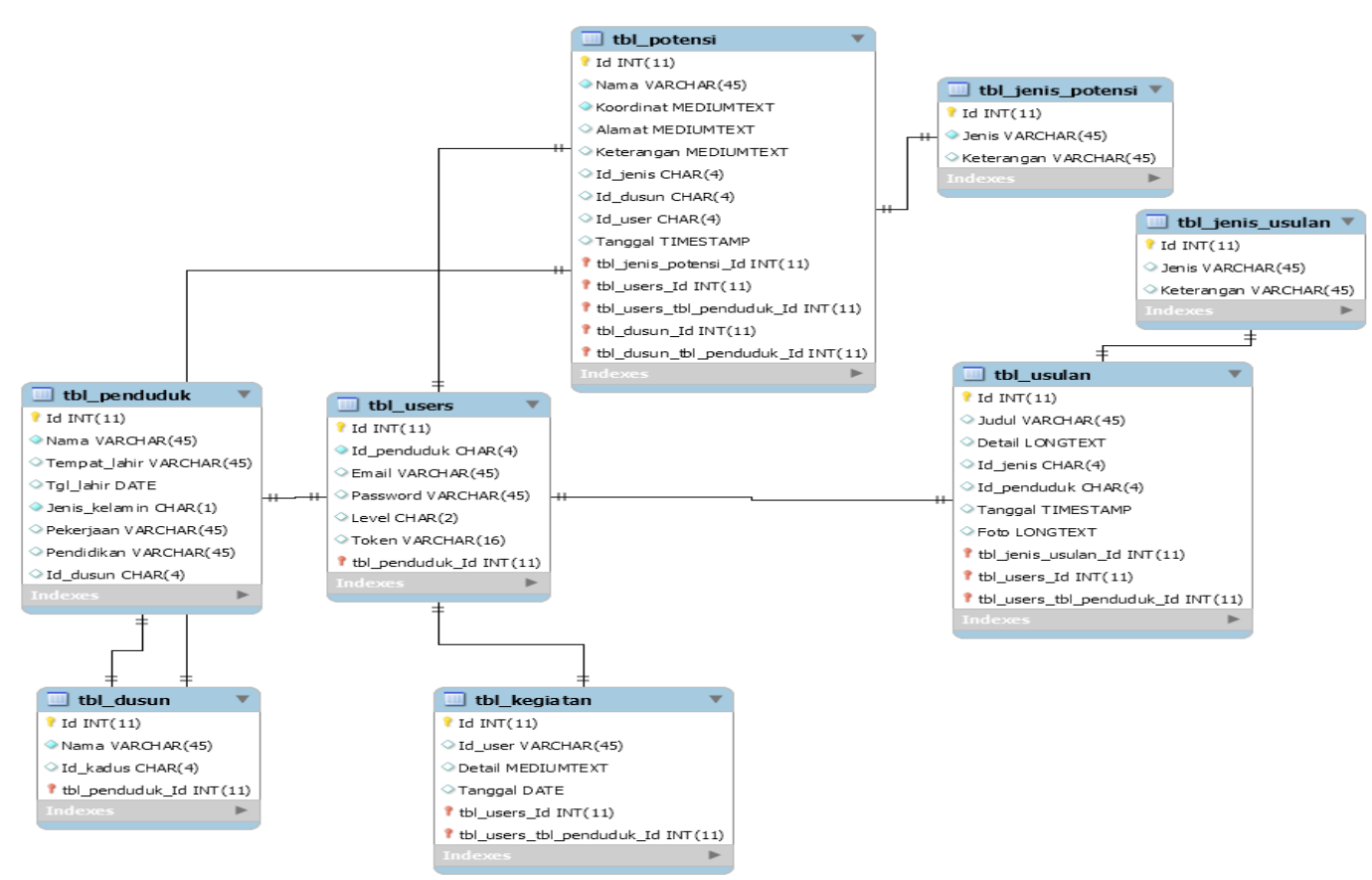

Gambar 2. OLTP program pembangunan desa

\subsection{Desain}

Dalam tahap desain, dibagi menjadi dua, yaitu desain tampilan dan desain fungsi. Desain tampilan dashboard memperhatikan elemen-elemen seperti tampilan grafik, warna, bentuk bagan, animasi, dan penempatan konten informasi. Perancangan layout dashboard mempertimbangkan hal-hal seperti jumlah frame, simetri dan proporsi frame, serta resolusi komputer. Perancangan mekanisme komunikasi dilakukan dengan tujuan untuk merancang struktur komunikasi antara pengguna dashboard, dalam merespon alert dan melakukan pelaporan. Perancangan kontrol navigasi meliputi upaya membagi informasi ke dalam beberapa layar yang berbeda, dengan menyediakan penghubung yang tepat. Navigasi memungkinkan pengguna melakukan drill-down, untuk mendapatkan informasi yang lebih detail. Secara umum desain fungsi dari sistem yang dirancang dapat dilihat pada gambar use case, seperti pada Gambar 3.

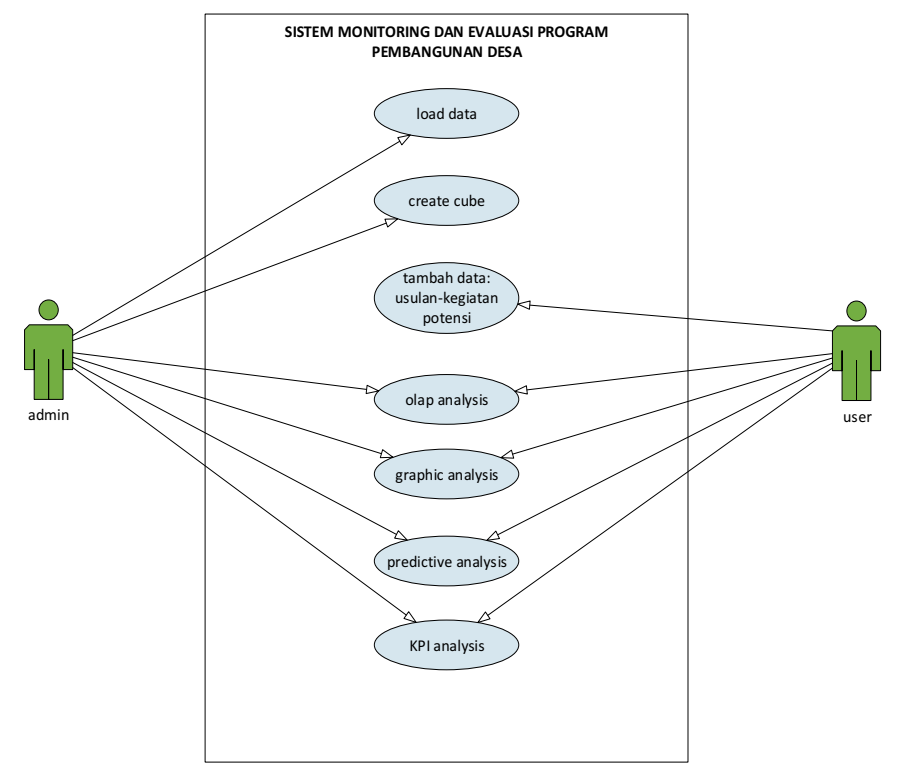

Gambar 3. Usescase Sistem Monitoring Evaluasi Program Pembangunan Desa 
Desain fungsi terdiri dari tiga bagian, yaitu desain fungsi monitoring, desain fungsi evaluasi dan desain fungsi prediksi. Desain fungsi merupakan bagian dari desain prototyping dalam pembangunan sistem yang menggunakan pendekatan user-centric. Prototype merupakan media yang digunakan untuk melihat kesesuaian antara kebutuhan pengguna dengan sistem yang direncanakan, sebelum diimplementasikan secara nyata. Dengan menggunakan prototype pembangunan dashboard menjadi lebih efisien, karena setiap kekeliruan yang terjadi akibat kesalahan persepsi dapat dideteksi lebih awal.

Desain fungsi monitoring dan evaluasi bertujuan memberikan tampilan visual untuk analisis permasalahan. Permasalahan yang dianalisis merupakan permasalahan yang telah dikategorikan berdasarkan identifikasi key perfomance indicator (KPI). Desain fungsi prediksi, bertujuan untuk menyediakan fungsi yang dapat melakukan analisis prediksi, seperti analisis kebutuhan dan ketersediaan sumberdaya (potensi).

Desain fungsi terdiri dari dua bagian yaitu bagian depan (front end) dan bagian belakang (back end). Bagian depan berfungsi sebagai tampilan user interface (UI )yang digunakan oleh publik user (user umum). Untuk dapat mengakses ke bagian depan tidak harus menggunakan password, sehingga bersifat umum. Sebaliknya bagian belakang berfungsi untuk mengelola sistem yang digunakan oleh administrator. Bagian belakang membutuhkan username dan password untuk dapat digunakan. Gambar 4 dan 5 adalah contoh tampilan halaman depan dan halaman dashboard desain aplikasi yang dikembangkan.

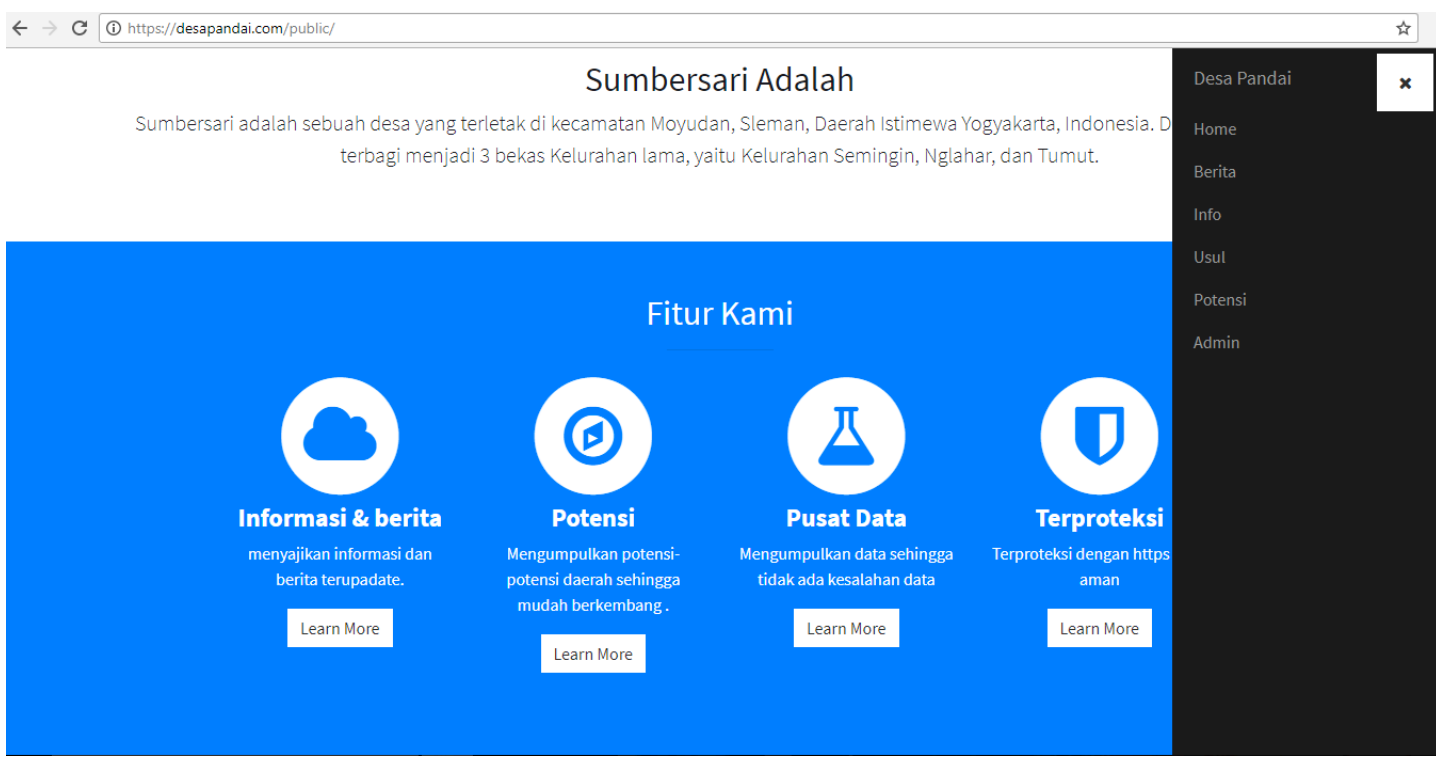

Gambar 4. Halaman depan (home): Fitur Kami

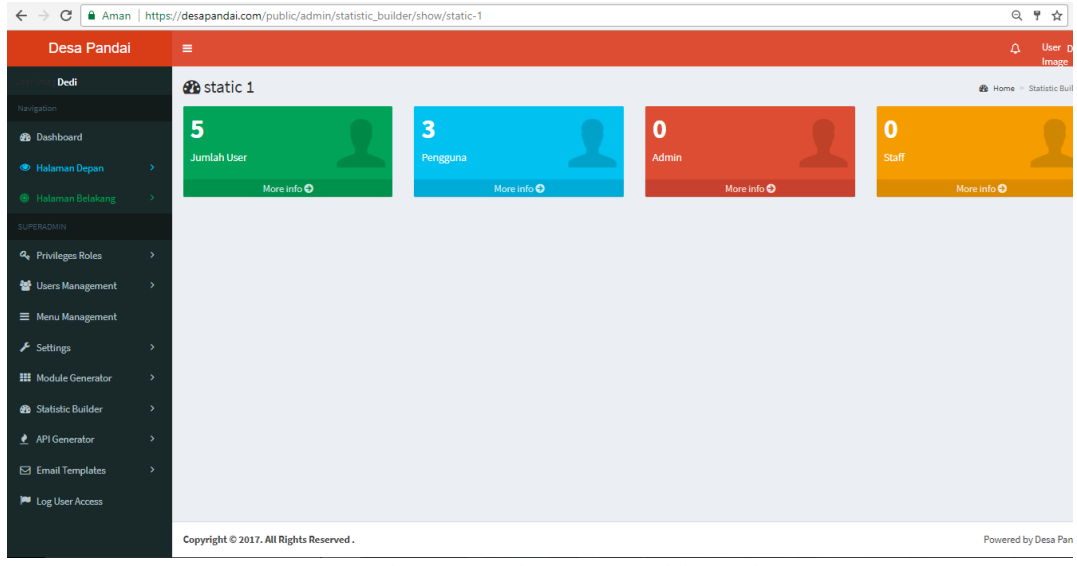

Gambar 5. Halaman Dashboard 


\section{KESIMPULAN}

1. Terdapat 4 (empat) key perfomance indicator (KPI) yang berhasil diidentifikasi dalam desain dashboard analisis sistem pengambilan keputusan untuk pembangunan desa yaitu; usulan program, kegiatan, potensi dan pengusul.

2. Penelitian ini menghasilkan suatu tampilan dashboard untuk pengambilan keputusan program pembangunan desa berdasarkan KPI yang telah diidentifikasi. Dashboard yang dibangun memiliki kemampuan analisis fakta yang berkaitan dengan kuantitas jumlah seperti jumlah program, jumlah kegiatan, jumlah potensi, jumlah pengusul program pembangunan desa yang dikaitkan dengan waktu, lokasi, deskripsi dan penjelasan yang dikaitkan dengan kebutuhan analisis untuk pengambilan keputusan.

\section{DAFTAR PUSTAKA}

[1] Few, Stephen, 2006, Information Dashboard Design, O'Reilly Media, Italy.

[2] Gonzalez, Tom, 2006, User-Centric Approach for Designing and Building Dashboards”; BrightPoint Consulting, Inc,.

[3] Novell, 2004, Secure Enterprise Dashboard: a Key to Business Agility, Novell White Paper.

[4] Eckerson, Wayne, 2006, Performance Dashboard, John Wiley and Sons, Canada.Vercellis C., 2009, Business Intelligence: Data Mining and Optimization for Decision Making, John Wiley \& Sons, Ltd. ISBN: 978-0-470-51138-1.

[5] Vercellis C., 2009, Business Intelligence : Data Mining and Optimization for Decision Making, John Wiley \& Sons, Ltd. ISBN: 978-0-470-51138-1.

[6] Negash S., 2004, Business Intelligence, Communications of the Association for Information Systems (Volume13, 2004) 177-195

[7] Posayanant S., Chareonngam C., 2010, Prototype KPIs for Rural Infrastructure Development The Practice of Sub-District Local Governments. International Journal of Productivity and Performance Management Vol. 59 No. 8, pp. 717-733.

[8] Dolan J.G., et al., 2013, Development and Initial Evaluation of A Treatment Decision Dashboard. BMC Medical Informatics and Decision Making, 13:51.

[9] Murray T., et al., 2013, A Prototype Facilitators Dashboard: Assessing and visualizing dialogue quality in Online deliberation for education and work. EEE' Submission

[10] Hewitt, Eleanor \& M. Bamberger. 1986. Monitoring and Evaluating Urban Development Programs. World Bank, Washington

[11] M. Muktiali. 2009. Penyusunan Instrumen Monitoring dan Evaluasi Manfaat Program Pembangunan di Kota Semarang. Riptek, Vol.3, No.2, Tahun 2009, Hal.: 11 - 20

[12] Solihin, Dadang. 2008. Teknik Penyusunan Indikator Kinerja Pembangunan. Bintek Perencanaan Penganggaran dan Monev Pembangunan Ikatan Widyaiswara Indonesia. Disampaikan di Hotel Grand Cempaka-Jakarta, 19 November 2008

[13] Hariyanti, E. 2008, Pengembangan Metodologi Pembangunan Information Dashboard untuk Monitoring Kinerja Organisasi. e-Indonesia Initiative 2008 (eII2008) Konferensi dan Temu Nasional Teknologi Informasi dan Komunikasi untuk Indonesia. Jakarta.

[14] Adisasmita, Raharjo, 2006, Pembangunan Pedesaan dan Perkotaan, Yogyakarta, Graha Ilmu 